\title{
In Planta Secretion of a Calreticulin by Migratory and Sedentary Stages of Root-Knot Nematode
}

\author{
Stéphanie Jaubert, ${ }^{1}$ Adina L. Milac, ${ }^{2}$ Andrei J. Petrescu, ${ }^{2}$ Janice de Almeida-Engler, ${ }^{1}$ Pierre Abad, ${ }^{1}$ and \\ Marie-Noëlle Rosso' \\ ${ }^{1}$ INRA-CNRS-UNSA, Plant-Microbe Interactions and Plant Health, 400 route des Chappes BP 167, 06903 Sophia Antipolis, \\ France; ${ }^{2}$ Structural Biochemistry Group, Institute of Biochemistry of the Romanian Academy, Splaiul Independentei 296, \\ 060031 Bucharest 17, Romania
}

Submitted 10 May 2005. Accepted 1 August 2005.

\begin{abstract}
Esophageal secretions from endoparasitic sedentary nematodes are thought to play key roles throughout plant parasitism, in particular during the invasion of the root tissue and the initiation and maintenance of the nematode feeding site (NFS) essential for nematode development. The secretion in planta of esophageal cell-wall-degrading enzymes by migratory juveniles has been shown, suggesting a role for these enzymes in the invasion phase. Nevertheless, the secretion of an esophageal gland protein into the NFS by nematode sedentary stages has never been demonstrated. The calreticulin Mi-CRT is a protein synthesized in the esophageal glands of the root-knot nematode Meloidogyne incognita. After three-dimensional modeling of the MiCRT protein, a surface peptide was selected to raise specific antibodies. In planta immunolocalization showed that Mi-CRT is secreted by migratory and sedentary stage nematodes, suggesting a role for Mi-CRT throughout parasitism. During the maintenance of the NFS, the secreted Mi-CRT was localized outside the nematode at the tip of the stylet. In addition, Mi-CRT accumulation was observed along the cell wall of the giant cells that compose the feeding site, providing evidence for a nematode esophageal protein secretion into the NFS.
\end{abstract}

Additional keywords: plant-parasitic nematode.

In plant-parasitic nematodes, esophageal secretions, also named stylet secretions, are synthesized in the esophageal subventral and dorsal glands and are secreted through the styleta hollow feeding spear connected to the esophagus-during parasitism. Stylet secretions are thought to play key roles throughout parasitism. The second-stage juvenile (J2) is the infective stage that invades the root tissue by penetrating the elongation zone and migrating along the vascular cylinder. After the invasion phase, the $\mathrm{J} 2$ inserts its stylet into root cells close to the vascular cylinder. In response to nematode signals, the selected cells redifferentiate into hypertrophied multinucleate feeding cells, providing the nematode with the nutrients required to complete its life cycle. In the case of root-knot nematodes (Meloidogyne spp.), the feeding cells named giant cells result from a series of karyokineses without cytokinesis. Five to seven giant cells compose the nematode feeding site

Corresponding author: Marie-Noëlle Rosso; Telephone: +33 492386 504; Fax: +33 492386 587; E-mail: rosso@antibes.inra.fr
(NFS) (Huang and Maggenti 1969). A gall embedding the NFS and the nematode is formed. Once the NFS is initiated, J2s becomes sedentary and develop into third- and fourth-stage juvenile ( $\mathrm{J} 3 \mathrm{~s}$ and $\mathrm{J} 4 \mathrm{~s}$, respectively) and finally into adult males or females. Males leave the root, whereas sedentary females remain feeding on the giant cells and extrude eggs on the root surface.

The assumption of a role for stylet secretions in the initiation and the maintenance of the feeding site is based on several cytological observations. First, the maintenance of the feeding site integrity is dependant on continuous stimulation by the nematode (Bird 1962). Second, during feeding, the nematode inserts its stylet through the cell wall of giant cells without piercing the plasma membrane, which becomes invaginated around the stylet (Williamson and Hussey 1996). Third, changes in the content, morphology, and activity of esophageal glands have been evidenced during parasitism (Bird 1983; Davis et al. 1994; Hussey and Mims 1990; Tytgat et al. 2002; Wyss et al. 1992).

Despite the identification of numerous genes specifically expressed in the esophageal glands (Huang et al. 2005; Vanholme et al. 2004), observations of secretion of the corresponding proteins in planta are scarce. Cellulases and pectinases have been shown to be secreted in planta by migratory J2 (Doyle and Lambert 2002; Wang et al. 1999), suggesting a role for secreted cell-wall-degrading enzymes in the weakening of the plant cell walls during the penetration and the migration of the nematode within the root tissues. A few proteins potentially involved in NFS induction and maintenance have been shown to be expressed in the esophageal glands of parasitic stages of the nematode and transported through the secretory vesicles along the gland cell extensions for secretion into the plant (Doyle and Lambert 2003; Hussey et al. 1990; Tytgat et al. 2004). Nevertheless, the secretion of a nematode esophageal gland protein into the feeding site has never been demonstrated.

A calreticulin-Mi-CRT-has been identified by protein sequencing of stylet secretions from Meloidogyne incognita freshly hatched J2 (Jaubert et al. 2002). As in Caenorhabditis elegans, a single calreticulin-encoding gene, $\mathrm{Mi}$-crt, was identified in $M$. incognita. Calreticulins are calcium-binding proteins highly conserved in plants and animals. They are present mainly in the endoplasmic reticulum, where they act as chaperone proteins. Moreover, calreticulins located in the nuclear envelope, in the cytoplasm, or on the cell surface are involved in the regulation of multiple functions, such as protein export from the nucleus (Holaska et al. 2002), mRNA degradation (Nickenig et 
al. 2002), or cell adhesion (Goicoechea et al. 2002). In addition, calreticulins regulate cell calcium homeostasy, thereby intervening in the regulation of metabolic pathways, cell-cycle, cell growth and differentiation, endocytosis, exocytosis, and secretion (Michalak et al. 2002). Calreticulins have been shown to be secreted in the host tissue by many parasites of vertebrates, such as the nematodes Necator americanus (Kasper et al. 2001) and Haemonchus contortus (Suchitra and Joshi 2005), the platyhelminth Schistosoma mansoni (Khalife et al. 1994), and the tick Amblyomma americanum (Kovacs et al. 1998). Although calreticulins have been shown to bind the $\mathrm{Clq}$ complement involved in the immune response (Suchitra and Joshi 2005), the function of calreticulins in host-parasite interactions is still unclear. Nevertheless, their presence in the secretions produced by a wide range of parasites supports the hypothesis of a role in parasitism (Ferreira et al. 2004).

The nematode calreticulin studied here (Mi-CRT) was isolated from stylet secretions collected after in vitro incubation of $\mathrm{J} 2$ in resorcinol. The corresponding gene, Mi-crt, was shown to be transcribed in juveniles and in adult stages. The protein Mi-CRT and its transcripts were localized in the subventral esophageal glands of infective J2 (Jaubert et al. 2002). Based on these results, it was hypothesized that the protein may be secreted in planta by parasitic stages of the nematode and have a role throughout parasitism. In this article, we investigated the in planta secretion of Mi-CRT throughout parasitism by immunocytochemistry on sections of infested tomato and Arabidopsis thaliana roots. We showed that the nematode protein is secreted into the plant tissues by migratory $\mathbf{J} 2$ and that it is secreted into the NFS by sedentary stages of the nematode. This result provides evidence that a nematode esophageal protein is secreted into the feeding site and suggests that Mi-CRT is necessary for the formation and maintenance of the NFS.

\section{RESULTS}

\section{Identification of Mi-CRT-specific peptides.}

Calreticulins are highly conserved in plants and animals and, globally, share $70 \%$ identity. To immunolocalize the nematode Mi-CRT during parasitism and to avoid cross reaction with calreticulins from the host, an anti-peptide antibody approach was developed. The Mi-CRT protein sequence was aligned with the calreticulin sequences from plants available in databases. Based on this alignment and on the analysis of the peptide antigenicity, we identified four Mi-CRT-specific peptides which could be used to produce a polyclonal serum specific to the nematode calreticulin (Fig. 1). The peptide HEVQI DGEKAESGELEA shared only three amino acids with the plant calreticulins. However, the antipeptide strategy usually is delicate to develop when information is lacking about the accessibility of the selected peptide in the native protein.

\section{Three-dimensional model of Mi-CRT.}

In order to locate the surface sequences of Mi-CRT and assess the accessibility of the Mi-CRT-specific peptides, we built a three-dimensional (3D) model of Mi-CRT using homology modeling. To this end, we used as template the X-ray structure of the dog calnexin, PDB code $1 \mathrm{jhn}$, which shows $35 \%$ sequence identity in the soluble part and $75 \%$ identity in the proline-rich P-domain with Mi-CRT, above the threshold generally accepted for homology modeling. The model comprises the region 15 to 352 of the Mi-CRT sequence (Fig. 2). This includes the peptides of interest and the stretches 45 to 54 and 198 to 203 which are missing from the template. However, aside from the stretch 1 to 15 , the model lacks the highly charged C-terminal domain (352 to 415) because this 63amino-acid region is missing from the crystal structure of dog calnexin, presumably due to its loose contacts with the core of the protein. The 3D model contains the main structural characteristics of calreticulin: an N-terminal all- $\beta$ globular domain, including one calcium binding site and a central P-domain "extended arm" containing the calreticulin repeated motifs 1 (I-X-D-P-(D/E)-A-X-K-P-E-D-W-D-(D/E)-) and 2 (-G-X-W-X-X$\mathrm{P}-\mathrm{X}-\mathrm{I}-\mathrm{N}-\mathrm{x}-\mathrm{P}-\mathrm{X}-\mathrm{Y}-\mathrm{-}$.

Analysis of the Mi-CRT model showed that the peptide HEVQIDGEKAESGELEA is predicted to be located on a hairpin exposed on the surface of the globular part of the protein (Fig. 2). The surface location of this peptide was confirmed further by measuring the relative side chain accessibility for water of each amino acid (data not shown). Based on these data, the prediction was made that the Mi-CRT-specific region might be used successfully to produce antipeptide polyclonal antibodies in order to investigate the localization of Mi-CRT in the roots during parasitism.

\section{Antipeptide analysis.}

After rat immunization with the selected HEVQIDGEKAE SGELEA peptide, the serum specificity to Mi-CRT first was determined by enzyme-linked immunosorbent assay (ELISA) on freshly hatched juveniles and healthy tomato root homogenates. The serum recognized an antigen in the nematode homogenate, whereas it did not react with plant root homogenate (data not shown). After protein gel blotting, the anti-Mi-CRTpeptide serum specifically bound to a protein band of the expected 50-kDa molecular weight on total $M$. incognita J2 homogenate (Fig. 3A). As expected from the low homology shared by the selected peptide and plant calreticulins (Fig. 1), no protein band was detected in healthy $A$. thaliana root homogenate (Fig. 3B). Immunofluorescence assays on freshly hatched preparasitic J2 showed that the anti-Mi-CRT-peptide serum bound specifically to the esophageal subventral glands and occasionally to their cytoplasmic extension (Fig. 3C and D). No signal was obtained in control assays where the preparasitic $\mathrm{J} 2 \mathrm{~s}$ were incubated in pre-immune serum or without the primary antibody (data not shown).

\section{Localization of Mi-CRT during parasitism.}

In order to have a complete view of Mi-CRT localization at different stages of parasitism, immunolocalizations were performed on migratory nematodes dissected from roots and on galls sectioned 1 to 21 days after inoculation (DAI) with $M$. incognita. Similar results were obtained on tomato and $A$. thaliana-infested roots. Migratory J2 were observed on root sections 1 DAI. The anti-Mi-CRT-peptide bound within root tissue along the migratory path of $\mathrm{J} 2$ (Fig. 3E and F). No signal was observed in the esophageal glands of migratory $\mathrm{J} 2$ on sections, probably because fixation conditions were optimized for plant tissue observation and may not be suitable for nematode esophageal glands. Hence, Mi-CRT expression in the nematode tissues was analyzed on migratory $\mathrm{J} 2$ dissected from infested roots. Immunofluorescence microscopy showed a strong signal in the subventral esophageal glands of the nematodes (Fig. 3G and H). Gland extensions were labeled in the presence of higher primary antibody concentrations, suggesting the trafficking of Mi-CRT in the glands of migratory $\mathrm{J} 2$. Observations of sedentary $\mathrm{J} 3$ were performed 15 DAI and accumulation of secreted Mi-CRT was detected clearly at the tip of the stylet of the nematode (Fig. 3I and J). Galls sectioned 21 DAI were used for observations on J4 and females. On J4, a strong signal was observed within the nematode in the secretory ampulla of the dorsal esophageal gland posterior to the stylet (Fig. 4A and B). Mi-CRT also 
was detected outside the nematode at the tip of the stylet and along the cell wall of the adjacent giant cells (Fig. 4A and B). DNA staining with di-aminido phenyl indol (DAPI) confirmed tissue preservation and labeled the multiple nuclei from the giant cells. By overlaying images taken with differential interference contrast and epifluorescence (fluorescein isothiocyanate and DAPI), we confirmed the localization of Mi-CRT in the nematode gland ampulla and along the plant cell wall in front of the stylet (Fig. 4B). Similar to J4, females were strongly labeled in the dorsal gland ampulla and Mi-CRT secretion was detected by a tiny labeling at the tip of the stylet (Fig. 4C and D). Mi-CRT accumulation also was clearly visible along the cell wall of adjacent giant cells (Fig. 4C and D). No signal was observed in control sections incubated with pre-immune serum (Fig. 4E and F). Mi-CRT was not detected in the intracellular compartment of giant cells. This absence of signal may be due to the confinement of the protein outside the cells or to a high dilution of the protein into the cytoplasm preventing its detection. In females, MiCRT also was visualized in the hypodermis and the gonads (data not shown).

\section{DISCUSSION}

In this study, we localized in planta a nematode-secreted esophageal protein, the calreticulin Mi-CRT, by immunocytochemistry. We showed that Mi-CRT is secreted in planta throughout parasitism. It is expressed in the subventral esophageal glands of $\mathrm{J} 2$ and in the dorsal gland of sedentary stages. Accumulation of the secreted Mi-CRT into the NFS was observed along the cell wall of the giant cells in front of the nematode head.

The in planta immunolocalization of Mi-CRT during parasitism was performed using specific antibodies directed against an Mi-CRT-peptide. The peptide antigen HEVQIDGE KAESGELEA was selected based on its low homology with plant calreticulins in order to avoid cross reactivity. The position of the peptide on the folded protein was assessed after 3D modeling of Mi-CRT using homology modeling. In recent years, only limited progress has been made in determining calreticulin structure and only the nuclear magnetic resonance structure of the central, proline-rich P-domain of rat calreticulin was available (PDB code 1hhn) (Ellgaard et al. 2001). However,

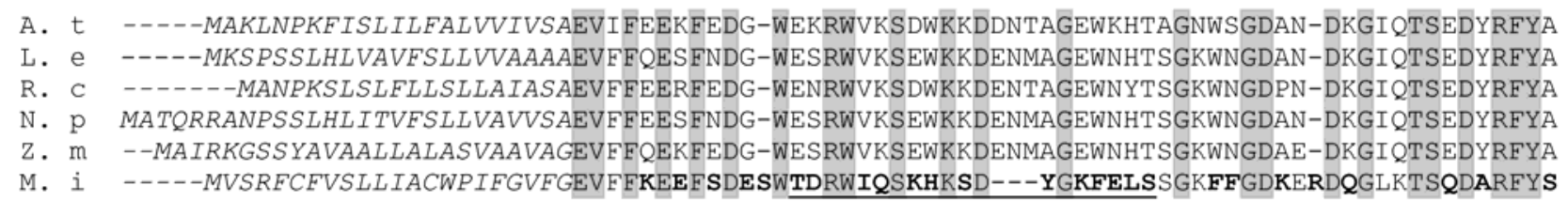

A. $t$ ISAEFP-EFSNKDKTLVFQFSVKHEQKLDCGGGYMKLLSDDVDQTKFGGDTPYSIMFGPDICGYSTKKVHAILTYNGTNHLIKKEV

L. e ISAEFP-EFSNKGKNLVFQFSVKHEQKLDCGGGYMKLLSGDVDQKKFGGDTPYSIMFGPDICGYSTKKVHAILTYNETNHLIKKEV

R. C ISAEFP-EFSNKDKTLVFQFSVKHEQKLDCGGGYMKLLSSSTDQKKFGGDTPYS IMFGPDICGYSTKKVHAILNYNDTNHLIKKEV

N. p ISAEFP-EFSNKGKNLVFQFSVKHEQKLDCGGGYMKLLSGDVDQKKFGGDTPYSIMFGPDICGYSTKKVHAILTYNDTNHLIKKEV

z. m ISAEYP-EFSNKDKTLVLQFSVKHEQKLDCGGGYVKLLGGDVDQKTLGGDTSYSI ISRPDISRYSTKKVHTILTKDGKNHLIKKDV

M. i ISAKFPKKFSSKGKTLVIQFSIKHEQEIDCGGGYLKLMASTINQEDFHGETPYHLMFGPDICGPGTKKVHVIINYKGKNQLIKKDI

A. $t$ PCETDQLTHVYTFVLRPDATYSILIDNVEKQTGSLYSDW̄DLLPAKKIKDPSAKKPEDWDDKEYIPDPEDTKPAGYDDIPKEIPDTD L. e PCETDQLTHVYTFILRPDATYSILIDNVEKQSGSLYSDWDILPPKKIKDPSAKKPEDWDDKEFIDDPEDKKPEGYDDIPEEITDPE

R. C PCETDQLTHVYTLVIRPDATYSILIDNVEKQTGSLYTDWDLLPPKKIKDPEAKKPEDWDEKEYIPDPEDKKPEGYDDIPKEIPDPD N. p PCETDQLTHVYTFILRPDATYSILIDNVEKQSGSLYSDWDLLPPKTIKDPSAKKPEDWDEKEFIDDPEDKKPEGYDDIPEEITDPD

Z. m PCQTDQLTHVYTFIIRPDATYSILIDNEEKHTGSIYEHWDILPPKKIKDPEAKKPEDWDDKEYIPDPEDKKPEGYDDIPKEI PDPD

M. i RCKDDVLTHLYTLILNPDNTHEVQIDGEKAESGELEA WWELLPEKKIKDPDAKKPEDWDETEYIDDPEDKKPEDWD-KPETIPDPD

A. $t$ AKKPEDWDDEEDGEWTAPTIPNPEYNGEWKPKKIKNPAYKGKWKAPMIDNPEFKDDPELYVFPKLKYVGVELWQVKSGSLFDNVLV

L. e AKKPEDWDDEEDGEWTAPTI PNPEYKGPWKAKKI KNPNYKGKWKAPMI DNPDFKDDPDLYVFPKLKYVGAELWQVKSGTLFDNVVI

R. C AKKPEDWDDEEDGEWTAPTIANPEYKGPWKPKKI KNPNYKGKWKAPMI DNPDFKDDPEIYVYPNLKYVGIELWQVKSGTLFDNVLI

N. p AKKPEDWDDEEDGEWTAPTIPNPEYKGPWKPKKIKNPNYKGKWKAPLIDNPDFKDDPDLYVFPKLKYVGVELWQVKSGTLFDNIVI

Z. I AKKPEDWDDEEDGEWTAPTIPNPEYKGPWKQKKIKNPNYQGKWKAPMIDNPDFKDDPYIYAFDSLKYIGIELWQVKSGTLFDNIII

M. i AKKPEDWDDDMDGEWEPPKIDNPNYKGEWKPKQI KNPNYKGKWIHPEIDNPDYKVDDELYMREDWGSVGIDIWQVKSGTIFDNI IV

A. $t$ SDDPEYAKKLAEETWGKHKDAEKAAFDEAEKKREEEESKDAPAESDAEEEAEDDDNEGDDSDNESKSEETKEAEETKEAEETDAAHD

L. e CDDPEFAKSIAEETWGKQKDAEKAAFEEAEKKREEEESKNAPAESDADEDDEADEADSDDADDKSDSKDEDTHDEL

R. C CNDPEYAKQLAEETWGKNKDAEKAAFEEAEKKKEEEESKDDPADSDADEDDDDADDTEGEDDGESKSDAAEDSAEDVHDEL------

N. p CDDPEYAKAIAEETWGKQKDAEKAAFEEAEKKREEEESKAAPADSDAEEDDDADDDSDDADDKSESKDDEAHDEL------------

z. m TDDPALAKTFAEETWGKHKEAEKAAFDEAEKKKEEEDAAKGGDDEDDDLEDEEDDEKADEDKADSDAEDGKDSDDEKHDEL------

M. i TDSIDEAKAHAKETFEPLRDAEKKQKEAADEEERKKFEEEEKKRKEEEESKKKDEDKDGDEEEDKDEEEEKKVEEEHDEL-------

A. $t$ EL

L. e --

R. C --

N. $\mathrm{p}--$

Z. $\mathrm{m}--$

M. $i$--

Fig. 1. Multiple sequence alignment of the predicted Mi-CRT protein with plant calreticulins. GenBank accession numbers: Meloidogyne incognita calreticulin AAL40720, Arabidopsis thaliana 1 O04151, Ricinus communis P93508, Nicotiana plumbaginifolia Q40401, and Zea mays Q9SP22. The predicted protein sequence of the Lycopersicon esculentum calreticulin was obtained from three expressed sequence tags available in the database (accession numbers AW033447, AW035234, and BM956641). The N-terminal signal peptides are in italics, conserved amino acids are shaded, and amino acids specific to Mi-CRT are bold. The Mi-CRT-specific peptides are underlined and the antigen peptide selected to produce polyclonal serum is boxed. 
the X-ray structure of the soluble part of dog calnexin is available (PDB code 1jhn) (Schrag et al. 2001) and the high amino acid sequence similarity between calnexins and calreticulins (Michalak et al. 2002) allowed the use of calnexin data for the molecular modeling of Mi-CRT structure. Analysis of the MiCRT-predicted 3D structure localized the selected peptide in a hairpin exposed to the surface of the globular part of protein. In addition, analysis of the Mi-CRT 3D structure showed that the $M$. incognita calreticulin presents the canonical 3D structure of the previous models of calreticulins, suggesting a similar role for this nematode protein.

Mi-CRT previously was shown to be synthesized in the subventral esophageal glands of freshly hatched preparasitic J2 and to be secreted in vitro after chemical induction by resorcinol (Jaubert et al. 2002). In the present study, we show that Mi-CRT also is expressed in the subventral glands of migratory $\mathrm{J} 2$ dissected from roots. Labeling of the cytoplasmic extensions of the subventral glands in preparasitic and migratory J2 suggested that Mi-CRT is secreted by the nematode during the invasion of the root. This was confirmed by the labeling of secreted Mi-CRT within the plant tissue along the migratory path of J2. In sedentary J4 and females, Mi-CRT was observed in the secretory ampulla of the dorsal esophageal gland. Previous studies of the esophageal gland modifications during parasitism indicated that the subventral esophageal glands are more active in the early phases of infection (i.e., the invasion of the root by $\mathrm{J} 2$ and the induction of the NFS), whereas the dorsal gland intervenes later, during the maintenance of the NFS (Bird 1983; Davis et al. 1994; Hussey and Mims 1990; Tytgat et al. 2002; Wyss et al. 1992). Here, we show that Mi-CRT is secreted by the subventral esophageal glands of $\mathrm{J} 2$ and the dorsal esophageal gland of sedentary J4 and females, suggesting that its expression is correlated to the secretory activity of the glands. The localization of Mi-CRT in the hypodermis and the gonads of females is in accordance with the expression profiles of calreticulin from the animal-parasitic nematode Dirofilaria immitis (Tsuji et al. 1998). In C. elegans, the single calreticulin gene crt- 1 is expressed in diverse tissues, including pharynx, hypodermis, uterus, and sperm (Park et al. 2001; Xu

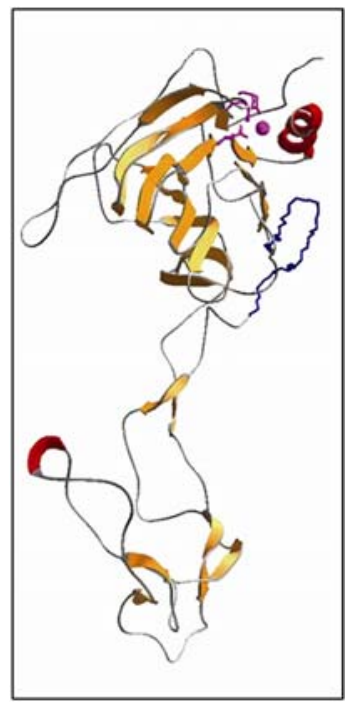

Fig. 2. Predicted three-dimensional (3D) structure of Mi-CRT and location of the Mi-CRT-specific peptide. The 3D model of Mi-CRT structure was built by homology modeling using the dog calnexin as template. Mi-CRT presents a globular domain including one calcium binding site and an extended-arm P-domain. The Mi-CRT-specific peptide HEVQIDGEKAESGELEA located at the surface of the globular domain is shown in blue, $\beta$ strands are shown in yellow, $\alpha$ helices are shown in red, and the Ca binding site, equivalent to that observed in calnexin, is shown in magenta. et al. 2001). Deletion mutants showed that crt- 1 is important for the proper development of $C$. elegans sperm and oocyte. These data suggest that calreticulin may have several functions in nematodes. The role of Mi-CRT in Meloidogyne spp. may encompass oogenesis and parasitism. Our results show that Mi-CRT is secreted in the plant tissues throughout parasitism. In our hands, in planta secretion of Mi-CRT by migratory $\mathrm{J} 2$ occasionally was observed, whereas secretion by sedentary stages was observed systematically, suggesting that Mi-CRT secretion by sedentary stages is a continuous process, although the amount of secreted Mi-CRT is low. The demonstration of the secretion of Mi-CRT throughout parasitism indicates that this protein could play a role in the nematode pathogenicity. Calreticulins are known to act as lectin-like chaperones involved in the correct folding of secreted glycoproteins. Therefore, $\mathrm{Mi}$ CRT could act indirectly during parasitism by driving the maturation of nematode secreted pathogenicity factors. Consistent with this hypothesis is the continuous expression of $\mathrm{Mi}$ CRT during nematode development (Jaubert et al. 2002). A similar function in secreted protein maturation has been proposed for the trypanosoma Leishmania donovani-secreted calreticulin (Debrabant et al. 2002).

Accumulation of Mi-CRT was observed at the tip of the stylet of sedentary stages but also along the cell wall of adjacent giant cells. The observed location of Mi-CRT on the cell wall of giant cells suggests that Mi-CRT is secreted outside the cell. A role in the extracellular space of feeding cells has been proposed for SYV46, an esophageal protein from the plantparasitic nematode Heterodera glycines that bears a functional domain similar to CLAVATA3 (Wang et al. 2005). Further immunological studies of Mi-CRT using electron microscopy could give crucial information about the precise location of the calreticulin within the cell wall, provided that Mi-CRT is abundant enough to be detected in ultrathin sections. However, in our observations, the absence of signal into the cytoplasm of giant cells could be due to a high dilution of the calreticulin when injected into the intracellular compartment.

It is tempting to suggest that Mi-CRT secreted outside the giant cells could be involved in the molecular dialogue between the plant and the nematode. A few studies report the secretion of calreticulins by plant cells. Tobacco calreticulin was localized on Nicotiana plumbaginifolia protoplast surfaces after auxin treatment. It was proposed that surface calreticulin could represent a specific $\mathrm{Ca}^{2+}$-storage mechanism or intervene in signal perception, cell shape, or cell adhesion via its lectin-like binding properties (Borisjuk et al. 1998). Interestingly, a local increase in auxin concentration in NFS has been evidenced (Goverse et al. 2000; Hutangura et al. 1999). Thus, we could suppose that a nematode calreticulin secreted outside the plant cell could intervene in a signal cascade involved in the induction of the NFS and that this signaling could be correlated with a modulation of the hormone balance. Moreover, plant calreticulins have been co-localized with callose deposits (Baluska et al. 1999; Bayer et al. 2004; Borisjuk et al. 1998). Callose is known to envelop the stylet of nematodes after perforation of the cell wall (Grundler et al. 1998; Hussey et al. 1992). Colocalization experiments of callose and calreticulin in the NFS would be interesting to perform in order to address the role of the secreted nematode calreticulin in the plant cell wall.

Several roles have been proposed for calreticulins secreted in the host by animal parasites, including the maturation of secreted proteins from the parasite, the regulation of $\mathrm{Ca}^{2+}$ in the host tissue, and the regulation of host defense responses to parasitism (Nakhasi et al. 1998; Suchitra and Joshi 2005). The observation that a phytonematode calreticulin is secreted into the feeding site strengthens the emerging idea that eukaryotic 
parasites of plants and animals may share basic mechanisms of parasitism (Davis et al. 2004; Jasmer et al. 2003). The development of RNA interference for the silencing of plant-parasitic nematode genes (Chen et al. 2005; Rosso et al. 2005; Urwin et al. 2002) offers the opportunity to further unravel the role of nematode-secreted proteins such as Mi-CRT in the plantnematode interaction.

\section{MATERIALS AND METHODS}

\section{Nematodes.}

M. incognita population Calissane nematodes were grown on tomato plants (Lycopersicon esculentum) cv. St. Pierre in a greenhouse. Eggs and freshly hatched $\mathrm{J} 2$ were extracted as described by Rosso and associates (1999).
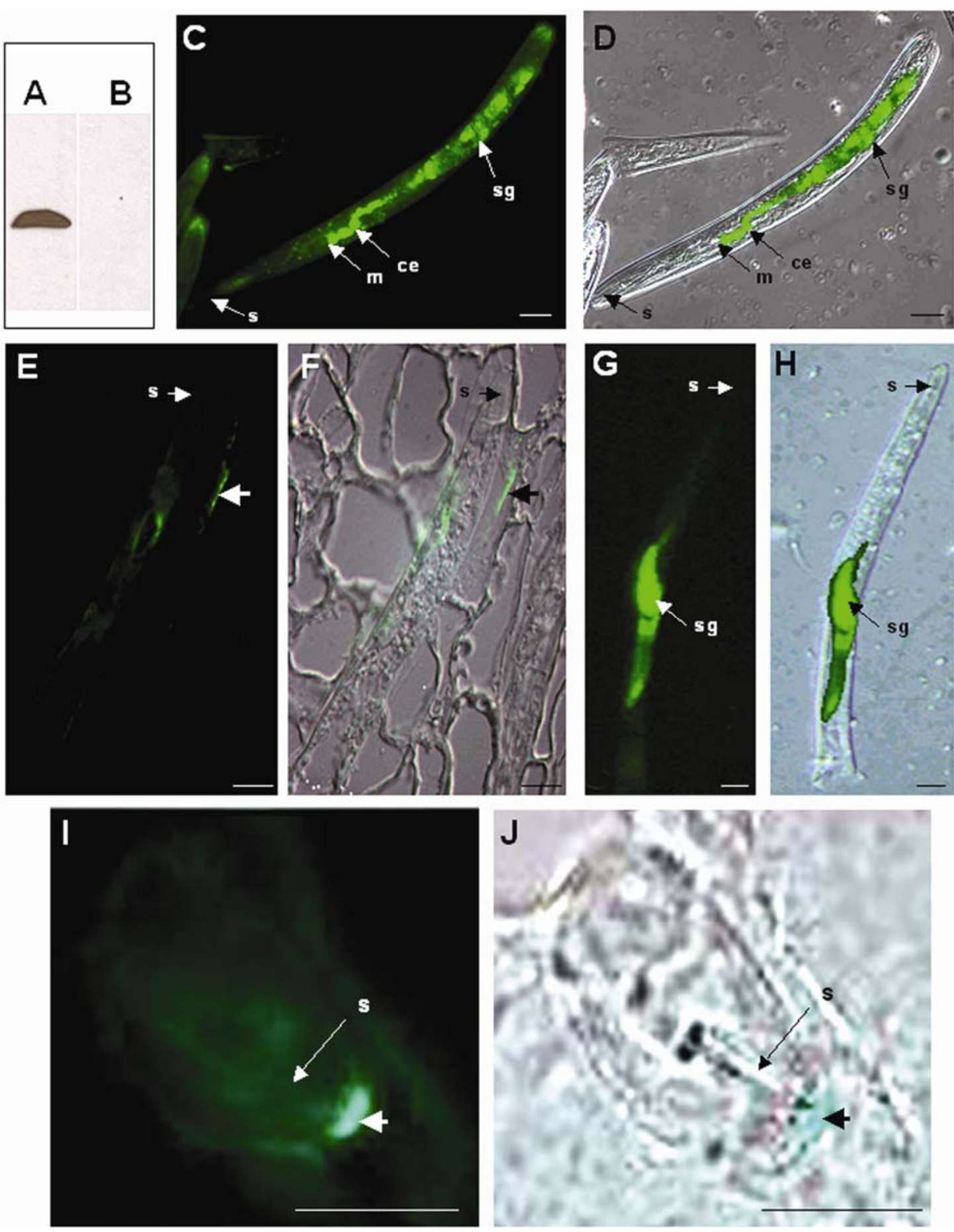

Fig. 3. Immunodetection of secreted Mi-CRT in Meloidogyne incognita second- and third-stage juveniles (J2 and J3, respectively). The specificity of the anti-Mi-CRT-peptide serum was analyzed by Western blot A, on total $M$. incognita J2 homogenate and $\mathbf{B}$, on uninfested A. thaliana root homogenate; $\mathbf{C}$ and D, localization of Mi-CRT in freshly hatched preparasitic J2. Mi-CRT was localized in the subventral glands (sg) and their cytoplasmic extension (ce); E and F, localization of secreted Mi-CRT along the migratory path of a J2 (arrow) in a 5- $\mu \mathrm{m}$ section of an A. thaliana-infested root, 1 day after inoculation (DAI); $\mathbf{G}$ and $\mathbf{H}$, localization of the Mi-CRT protein in a migratory $\mathbf{J} 2$ dissected from tomato roots 1 DAI; $\mathbf{I}$ and $\mathbf{J}$, localization of the secreted Mi-CRT at the tip of the stylet of a J3 (arrow) in a 20- $\mu \mathrm{m}$ cryosection of a tomato-infested root. C, E, G, and I, Observations with an fluorescein isothiocyanate (FITC) filter; D, $\mathbf{F}, \mathbf{H}$, and $\mathbf{J}$, overlay of differential interference contrast and FITC images; m, metacarpus; s, stylet. Scale bars $=10 \mu \mathrm{m}$. 


\section{D modeling of Mi-CRT.}

The 3D model of Mi-CRT was built by homology modeling. Suitable templates were identified in structural databases by fold recognition techniques (Kelley et al. 2000). The Mi-CRT sequence was first aligned with the selected templates with MULTALIN (Corpet 1988). This alignment was further optimized manually and tuned to fit information on secondary structure. The predicted Mi-CRT secondary structure was obtained by using the most successful methods ranked by CASP4 (Venclovas et al. 2001), PHD (Rost and Sander 1994), and SSPRO (Baldi et al. 1999). A 3D model of Mi-CRT1 was built based on the optimized sequence alignment in overlapping regions. This model was improved further by simulated annealing in nonconserved loops and repeated rounds of energy minimization and global simulated annealing in order to relieve steric conflicts. The structure modeling, refinement, and analysis were performed by using the programs Insight II, Discover, Homology, Delphy, and Affinity (Accelrys, San Diego, CA, U.S.A.), on a Silicon Graphics Octane 2 station. The accessibility was calculated by using the NACCESS software (Hubbard and Thornton 1993).

\section{Polyclonal serum production and analysis.}

The Mi-CRT-specific peptide was linked to a carrier protein (the keyhole limpet hemocyanin) and used as immunogen to immunize rats intradermally for polyclonal sera production (COVALAB, Lyon, France). The immunoreactivity of the sera was tested by ELISA. The specificity of the serum was checked by Western blot. Soluble proteins $(13 \mu \mathrm{g})$ from preparasitic $\mathrm{J} 2$ or healthy $A$. thaliana roots were blotted. The membrane was blocked and incubated with a $1 / 50$ dilution of the anti-Mi-CRT serum and then with the anti-rat horseradish
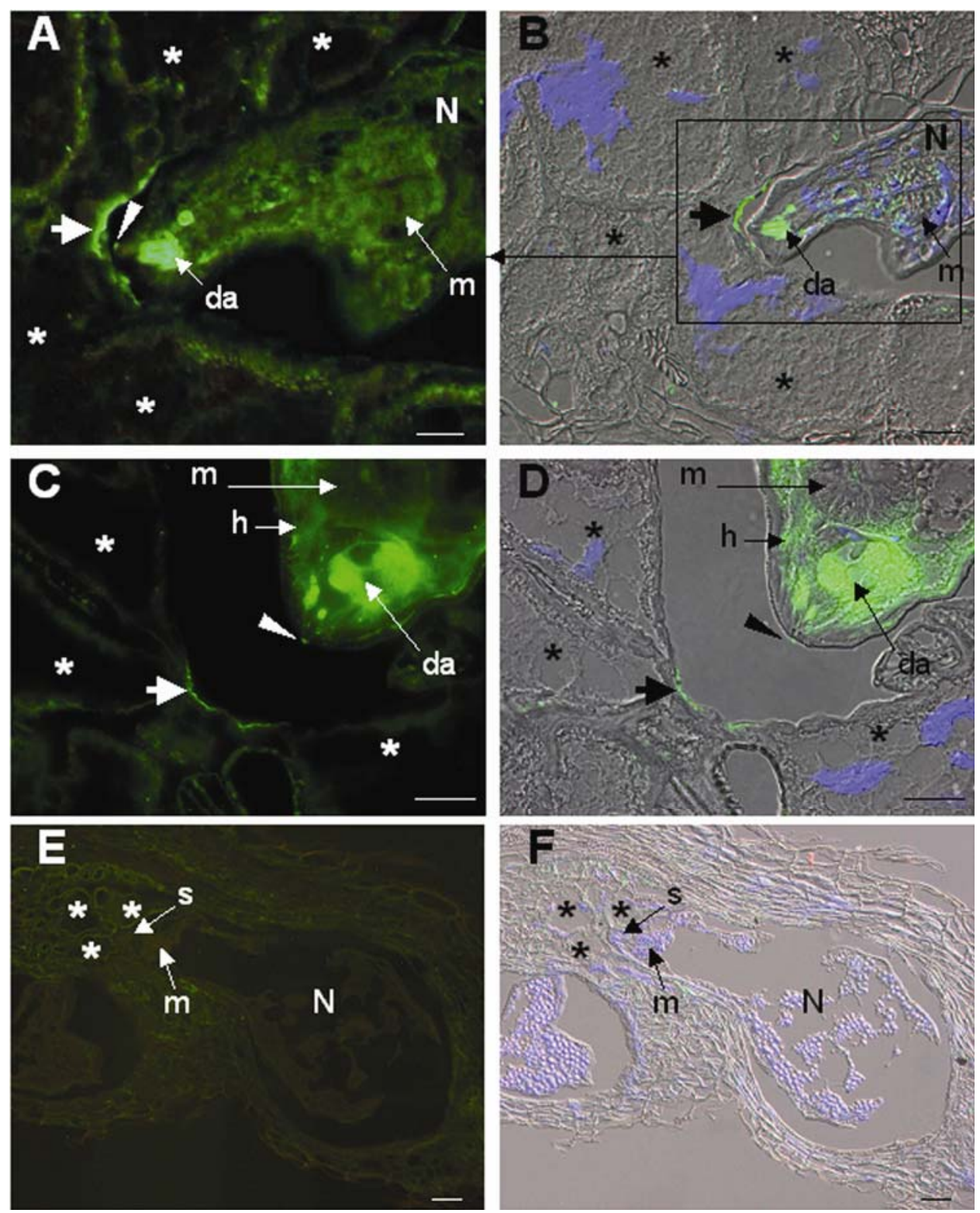

Fig. 4. Mi-CRT localization in sectioned Arabidopsis. thaliana galls ( $5 \mu \mathrm{m})$ containing M. incognita fourth-stage juveniles (J4s) and females. A and B, Gall containing a J4 nematode, 21 days after inoculation (DAI), showing the Mi-CRT protein in the dorsal gland ampulla (da), at the tip of the stylet (arrowhead), and along the cell wall of adjacent giant cells (arrow). C and D, Gall containing a female, 21 DAI, showing Mi-CRT in the hypodermis of the nematode (h), the dorsal gland ampulla (da), at the tip of the stylet (arrowhead), and along the cell wall of adjacent giant cells (arrow). E and F, Gall containing a female, 21 DAI, incubated with pre-immune serum. A, C, and E, Observations with an fluorescein isothiocyanate (FITC) filter; B, D, and F, overlays of FITC, differential interference contrast, and di-aminido phenyl indol-stained nuclei images; m, metacarpus; N, nematode; s, stylet. Giant cells are indicated by asterisks. Scale bars $=10 \mu \mathrm{m}$. 
peroxidase conjugated secondary antibody (Sigma-Aldrich, Lyon, France). The membranes were developed using the ECL Western blotting analysis system (GE Healthcare, Orsay, France) according to the manufacturer's instructions.

\section{Immunolocalization on $\mathbf{J} 2$.}

Pre-parasitic freshly hatched $\mathrm{J} 2$ were fixed in phosphate buffer saline (PBS) $2 \%$ paraformaldehyde for $18 \mathrm{~h}$ at $4^{\circ} \mathrm{C}$ and $4 \mathrm{~h}$ at room temperature. Parasitic J2 were dissected from infested tomato roots $48 \mathrm{~h}$ after inoculation. To facilitate the extraction of parasitic nematodes, infested roots were incubated for $16 \mathrm{~h}$ at $4^{\circ} \mathrm{C}$ in a cell-wall-degrading enzyme mix: Pectinex (15\%) (Realco, Louvain-la-neuve, Belgium) and Celluclast (30\%) (Realco). Infested roots were grounded and parasitic nematodes were purified by sucrose gradient centrifugations. Purified parasitic $\mathrm{J} 2$ were fixed in PBS $2 \%$ paraformaldehyde for $24 \mathrm{~h}$ at $22^{\circ} \mathrm{C}$. Immunolocalization on $M$. incognita preparasitic and parasitic $\mathrm{J} 2$ were performed as described by Jaubert and associates (2002) by incubating nematodes with a $1 / 4$ dilution of the anti-Mi-CRT serum and a $1 / 250$ dilution of anti-rat fluorescein isothiocyanate-conjugated secondary antibody (Sigma-Aldrich).

\section{Immunolocalization in cryosections of tomato galls.}

Cryosections (20 $\mu \mathrm{m}$ thick) were performed on L. esculentum cv. St. Pierre tomato plants inoculated with M. incognita. Galls were collected, fixed in PBS $2 \%$ paraformaldehyde at room temperature for $3 \mathrm{~h}$, washed in PBS, and placed in $10 \%$ dimethyl sulfoxide in PBS at room temperature for $30 \mathrm{~min}$ for cryoprotection of the root tissue. Galls were dried quickly on absorbing paper, positioned for longitudinal sectioning in liquid cryomatrix (CML, Nemours, France) within capsules, and frozen in liquid nitrogen for $8 \mathrm{~s}$ of prior sectioning. Sections were cut at $-20^{\circ} \mathrm{C}$ in a cryostat Jung CM 1800 (Leica Microsystems, Wetzlar. Germany), placed on poly-L-lysine glass microscope slides, postfixed for $5 \mathrm{~min}$ in PBS $2 \%$ paraformaldehyde, and washed in PBS. Sections were blocked and incubated with the anti-Mi-CRT serum and with the secondary antibody as described above. Sections were observed with an Axioplan 2 microscope (Carl Zeiss, Jena, Germany) equipped for epifluorescence microscopy, and images were collected with a digital Axiocam (Zeiss).

\section{Immunolocalization in semi-thin sections of Arabidopsis.}

Roots of $A$. thaliana cv. WS were inoculated with $M$. incognita and fixed in $4 \%$ formaldehyde in $50 \mathrm{mM}$ Pipes buffer ( $\mathrm{pH}$ 6.9). Dissected Arabidopsis galls at various time points after inoculation $(1,10$, and $21 \mathrm{DAI})$ were dehydrated, embedded in butyl-methylmethacrylate (Kronenberger et al. 1993), sectioned $(5 \mu \mathrm{m})$, and affixed to Poly-L-Lysine-coated slides.

Slides containing sectioned feeding sites were incubated with acetone for $30 \mathrm{~min}$ to remove the plastic. Primary and secondary antibodies were diluted 50- and 300-fold, respectively, in blocking solution ( $1 \%$ bovine serum albumin in 50 $\mathrm{mM}$ Pipes, $\mathrm{pH}$ 6.9). Sections were incubated with blocking solution for $30 \mathrm{~min}$ and overnight at $4^{\circ} \mathrm{C}$ with the anti-Mi-CRT serum. As controls, sections were incubated with pre-immune serum or without primary antibodies. After two washes in Pipes buffer and one in blocking solution, sectioned galls were incubated for $2 \mathrm{~h}$ at $37^{\circ} \mathrm{C}$ with the anti-rat fluorescein isothiocyanate-conjugated secondary antibody (Sigma-Aldrich). DNA was stained with 4',6-diamidino-2-phenylindole (SigmaAldrich) at $1 \mu \mathrm{g} / \mathrm{ml}$ in Pipes buffer and rinsed briefly in deionized water to remove salts. Mounted slides (ProLong antifade kit; Invitrogen Molecular Probes, Eugene, OR, U.S.A.) were observed with a microscope (Axioplan 2; Zeiss) equipped for epifluorescence microscopy and differential interference con- trast optics, and images were collected with a digital Axiocam (Zeiss).

\section{ACKNOWLEDGMENTS}

This work was supported by the European Union project QLRT-199901501, the Region Provence-Alpes-Côte d'Azur, and the Institut National de la Recherche Agronomique. We thank C. Castella and C. Roques for technical assistance.

\section{LITERATURE CITED}

Baldi, P., Brunak, S., Frasconi, P., Pollastri, G., and Soda, G. 1999. Exploiting the past and the future in protein secondary structure prediction. Bioinformatics 15:937-946.

Baluska, F., Samaj, J., Napier, R., and Volkmann, D. 1999. Maize calreticulin localizes preferentially to plasmodesmata in root apex. Plant J. 19:481-488.

Bayer, E., Thomas, C. L., and Maule, A. 2004. Plasmodesmata in Arabidopsis thaliana suspension cells. Protoplasma 223:93-102.

Bird, A.F. 1962. The inducement of giant cells by Meloidogyne javanica. Nematologica 8:1-10.

Bird, A. F. 1983. Changes in the dimensions of the esophageal glands in root-knot nematodes during the onset of parasitism. Int. J. Parasitol. 13:343-348.

Borisjuk, N., Sitailo, L., Adler, K., Malysheva, L., Tewes, A., Borisjuk, L., and Manteuffel, R. 1998. Calreticulin expression in plant cells: developmental regulation, tissue specificity and intracellular distribution. Planta 206:504-514.

Chen, Q., Rehman, S., Smant, G., and Jones, J. T. 2005. Functional Analysis of Pathogenicity Proteins of the Potato Cyst Nematode Globodera rostochiensis Using RNAi. Mol. Plant-Microbe Interact. 18:621-625.

Corpet, F. 1988. Multiple sequence alignment with hierarchical clustering. Nucleic Acids Res. 16:10881-10890.

Davis, E. L., Allen, R., and Hussey, R. S. 1994. Developmental expression of esophageal gland antigens and their detection in stylet secretions of Meloidogyne incognita. Fundam. Appl. Nematol. 17:255-262.

Davis, E. L., Hussey, R. S., and Baum, T. J. 2004. Getting to the roots of parasitism by nematodes. Trends Parasitol. 20:134-141.

Debrabant, A., Lee, N., Pogue, G. P., Dwyer, D. M., and Nakhasi, H. L. 2002. Expression of calreticulin P-domain results in impairment of secretory pathway in Leishmania donovani and reduced parasite survival in macrophages. Int. J. Parasitol. 32:1423-1434.

Doyle, E. A., and Lambert, K. N. 2002. Cloning and characterization of an esophageal-gland-specific pectate lyase from the root-knot nematode Meloidogyne javanica. Mol. Plant-Microbe Interact. 15:549-556.

Doyle, E. A., and Lambert, K. N. 2003. Meloidogyne javanica chorismate mutase 1 alters plant cell development. Mol. Plant-Microbe Interact. 16:123-131.

Ellgaard, L., Riek, R., Herrmann, T., Guntert, P., Braun, D., Helenius, A., and Wuthrich, K. 2001. NMR structure of the calreticulin P-domain. Proc. Natl. Acad. Sci. U.S.A. 98:3133-3138.

Ferreira, V., Molina, M.C., Valck, C., Rojas, A., Aguilar, L., Ramirez, G., Schwaeble, W., and Ferreira, A. 2004. Role of calreticulin from parasites in its interaction with vertebrate hosts. Mol. Immunol. 4:1279-1291.

Goicoechea, S., Pallero, M. A., Eggleton, P., Michalak, M., and MurphyUllrich, J. E. 2002. The anti-adhesive activity of thrombospondin is mediated by the N-terminal domain of cell surface calreticulin. J. Biol. Chem. 277:37219-37228.

Goverse, A., de Almeida Engler, J., Verhees, J., van der Krol, S., Helder, J., and Gheysen, G. 2000. Cell cycle activation by plant parasitic nematodes. Plant Mol. Biol. 43:747-761.

Grundler, F. M. W., Sobczak, M., and Golinowski, W. 1998. Formation of wall openings in root cells of Arabidopsis thaliana following infection by the plant-parasitic nematode Heterodera schachtii. Eur. J. Plant Pathol. 104:545-551.

Holaska, J. M., Black, B. E., Rastinejad, F., and Paschal, B. M. 2002. $\mathrm{Ca}(2+)$-dependent nuclear export mediated by calreticulin. Mol. Cell. Biol. 22:6286-6297.

Huang, C. S., and Maggenti, A. R. 1969. Mitotic aberrations and nuclear changes in developing giant cells in Vicia faba caused by the root-knot nematode Meloidogyne javanica. Phytopathology 59:445-447.

Huang, G., Dong, R., Allan, R., Davis, E. L., Baum, T. J., and Hussey, R. S. 2005. Developmental expression and molecular analysis of two Meloidogyne incognita pectate lyase genes. Int. J. Parasitol. 35:685-692.

Hubbard, S. J., and Thornton, J. M. 1993. NACCESS (computer software) Department of Biochemistry and Molecular Biology, University College, London. 
Hussey, R. S., and Mims, C. W. 1990. Ultrastructure of esophageal glands and their secretory granules in the root-knot nematode Meloidogyne incognita. Protoplasma 156:9-18.

Hussey, R. S., Mims, C. W., and Westcott, S. W. 1992. Ultrastructure of root cortical cells parasitized by the ring nematode Criconemella xenoplax. Protoplasma 167:55-65.

Hussey, R. S., Paguio, O. R., and Seabury, F. 1990. Localization and purification of a secretory protein from the esophageal glands of Meloidogyne incognita with a monoclonal antibody. Phytopathology 80:709714.

Hutangura, P., Mathesius, U., Jones, M. G. K., and Rolfe, B. G. 1999. Auxin induction is a trigger for root gall formation caused by root-knot nematodes in white clover and is associated with the activation of the flavonoid pathway. Aust. J. Plant Physiol. 26:221-231.

Jasmer, D. P., Goverse, A., and Smant, G. 2003. Parasitic nematode interactions with mammals and plants. Annu. Rev. Phytopathol. 41:245270

Jaubert, S., Ledger, T. N., Laffaire, J. B., Piotte, C., Abad, P., and Rosso, M. N. 2002. Direct identification of stylet secreted proteins from rootknot nematodes by a proteomic approach. Mol. Biochem. Parasitol. 121:205-211.

Kasper, G., Brown, A., Eberl, M., Vallar, L., Kieffer, N., Berry, C. Girdwood, K., Eggleton, P., Quinnell, R., and Pritchard, D. I. 2001. A calreticulin-like molecule from the human hookworm Necator americanus interacts with $\mathrm{C} 1 \mathrm{q}$ and the cytoplasmic signaling domains of some integrins. Parasite Immunol. (Oxf.) 23:141-152.

Kelley, L. A., MacCallum, R. M., and Sternberg, M. J. E. 2000. Enhanced genome annotation using structural profiles in the Program 3D-PSSM. J. Mol. Biol. 299:499-520.

Khalife, J., Liu, J. L., Pierce, R., Porchet, E., Godin, C., and Capron, A. 1994. Characterization and localization of Schistosoma mansoni calreticulin Sm58. Parasitology 108:527-532.

Kronenberger, J., Desprez, T., Höfte, H., Caboche, M., and Traas, J. 1993. A methacrylate embedding procedure developed for immunolocalization on plant tissues is also compatible with in situ hybridization. Cell Biol. Int. 17:1013-1021.

Kovacs, H., Campbell, I. D., Strong, P., Johnson, S., Ward, F. J., Reid, K B., and Eggleton, P. 1998. Evidence that C1q binds specifically to $\mathrm{CH} 2-$ like immunoglobulin gamma motifs present in the autoantigen calreticulin and interferes with complement activation. Biochemistry 37:17865-17874

Michalak, M., Robert Parker, J. M., and Opas, M. 2002. Ca2+ signaling and calcium binding chaperones of the endoplasmic reticulum. Cell Calcium 32:269-278

Nakhasi, H. L., Pogue, G. P., Duncan, R. C., Joshi, M., Atreya, C. D., Lee, N. S., and Dwyer, D. M. 1998. Implications of calreticulin function in parasite biology. Parasitol. Today 14:157-160.

Nickenig, G., Michaelsen, F., Muller, C., Berger, A., Vogel, T., Sachinidis, A., Vetter, H., and Bohm, M. 2002. Destabilization of AT(1) receptor mRNA by calreticulin. Circ. Res. 90:53-58.

Park, B. J., Lee, D. G., Yu, J. R., Jung, S. K., Choi, K., Kim, Y. S., Lee, J. I., Kwon, J. Y., Singson, A., Song, W. K., Eom, S. H., Park, C. S., Kim, D. H., Bandyopadhyay, J., Ahnn, J., and Lee, J. H. 2001. Calreticulin, a calcium-binding molecular chaperone, is required for stress response and fertility in Caenorhabditis elegans. Mol. Biol. Cell 12:2835-2845.
Rosso, M. N., Dubrana, M. P., Cimbolini, N., Jaubert, S., and Abad, P. 2005. Application of RNA interference to root-knot nematode genes encoding esophageal gland proteins: A functional analysis tool for nematode parasitism genes. Mol. Plant-Microbe Interact. 18:615-620.

Rosso, M. N., Favery, B., Piotte, C., Arthaud, L., De Boer, J. M., Hussey, R. S., Bakker, J., Baum, T. J., and Abad, P. 1999. Isolation of a cDNA encoding a beta-1,4-endoglucanase in the root-knot nematode Meloidogyne incognita and expression analysis during plant parasitism. Mol. Plant-Microbe Interact. 12:585-591.

Rost, B., and Sander, C. 1994. Combining evolutionary information and neural networks to predict protein secondary structure. Proteins 19:5572 .

Schrag, J. D., Bergeron, J. J., Li, Y., Borisova, S., Hahn, M., Thomas, D. Y, and Cygler, M. 2001. The structure of calnexin, an ER chaperone involved in quality control of protein folding. Mol. Cell. 8:633-644.

Suchitra, S., and Joshi, P. 2005. Characterization of Haemonchus contortus calreticulin suggests its role in feeding and immune evasion by the parasite. Biochim. Biophys. Acta 1722:293-303.

Tsuji, N., Morales, T. H., Ozols, V. V., Carmody, A. B., and Chandrashekar, R. 1998. Molecular characterization of a calcium-binding protein from the filarial parasite Dirofilaria immitis. Mol. Biochem. Parasitol. 97:69-79.

Tytgat, T., De Meutter, J., Vanholme, B., Claeys, M., Verreijdt, L., Gheysen, G., and Coomans, A. 2002. Development and pharyngeal gland activities of Heterodera schachtii infecting Arabidopsis thaliana roots. Nematology 4:899-908.

Tytgat, T., Vanholme, B., De Meutter, J., Claeys, M., Couvreur, M., Vanhoutte, I., Gheysen, G., Van Criekinge, W., Borgonie, G., Coomans, A., and Gheysen, G. 2004. A new class of ubiquitin extension proteins secreted by the dorsal pharyngeal gland in plant parasitic cyst nematodes. Mol Plant-Microbe Interact. 17:846-852.

Urwin, P. E., Lilley, C. J., and Atkinson, H. J. 2002. Ingestion of doublestranded RNA by preparasitic juvenile cyst nematodes leads to RNA interference. Mol. Plant-Microbe Interact. 15:747-752.

Vanholme, B., De Meutter, J., Tytgat, T., Van Montagu, M., Coomans, A., and Gheysen, G. 2004. Secretions of plant-parasitic nematodes: a molecular update. Gene 332:13-27.

Venclovas, C., Zemla, A., Fidelis, K., and Moult, J. 2001. Comparison of performance in successive CASP Experiments. Proteins Suppl. 5:163170.

Wang, X., Meyers, D., Yan, Y., Baum, T., Smant, G., Hussey, R., and Davis, E. 1999. In planta localization of a $\beta$-1,4-endoglucanase secreted by Heterodera glycines. Mol. Plant-Microbe Interact. 12:64-67.

Wang, X., Mitchum, M. G., Gao, B., Li, C., Diab, H., Baum, T. J., Hussey, R. S., and Davis, E. L. 2005. A parasitism gene from a plant-parasitic nematode with function similar to CLAVATA3/ESR (CLE) of Arabidopsis thaliana. Mol. Plant Pathol. 6:187-191.

Williamson, V. M., and Hussey, R. S. 1996. Nematode pathogenesis and resistance in plants. Plant Cell 8:1735-1745.

Wyss, U., Grundler, F. M. W., and Münch, A. 1992. The parasitic behaviour of second stage juveniles of Meloidogyne incognita in roots of Arabidopsis thaliana. Nematologica 38:98-111.

Xu, K., Tavernarakis, N., and Driscoll, M. 2001. Necrotic cell death in $C$. elegans requires the function of calreticulin and regulators of $\mathrm{Ca}_{2}^{+}$release from the endoplasmic reticulum. Neuron 31:957-971. 